Journal of Educational Method and Technology Vol. 2 No. 2, Agustus 2019

P-ISSN 2622-8459 E-ISSN 2622-8467

http://ejournal.unima.ac.id/index.php/jemtec

\title{
The Effectiveness of Question and Answer Technique in Teaching Reading Comprehension at SMP Negeri 3 Ratahan
}

T Mogea ${ }^{1}$

${ }^{1}$ Universitas Negeri Manado, Indonesia

corresponding author: ${ }^{1}$ tinimogea@unima.ac.id

\begin{abstract}
This research was conducted with the purpose to develop students' reading comprehension of descriptive text through question and answer technique. This study is classified as quantitative through pre-experimental design with one group pre-test and post-test design. The population of this research is the students of SMP Negeri 3 Ratahan. It was limited only to the second year studens. There were 30 students. The data were collected through test. The first test is pre-test, the teacher intends to know the students' reading comprehension without using question and answer technique. The second test is posttest in which the teacher has used question and answer technique in teaching reading comprehension. The result shows that the scores of the students in post-test are higher then those in pre-test. This is shown by the mean score of pre-test which is 5.5 and mean score of post-test which is 7.8
\end{abstract}

Keywords: Question and Answer Technique; Reading Comprehension

\section{Introduction}

Language is a communication tool for human life. Language is used to express feelings, emotions, ideas, and desires to one another. According to Webster (1970:79) that "Language is a systematic means of communicating ideas, of feelings". It is clear that language is for communication of ideas, feelings and desires.

English is an international language used all over the world, for education, technology, political and commercial purposes. Preble (1962:716) points out that "Language is the expression and communication emotions or ideas between human beings by means of speech and hearing, the sounds spoken and heard being systemized and confirmed by usange among a given people over a period of time." This definition indicates that language is the tool of communication used by its users to express emotions, ideas, by means of speech and hearing.

There are some factors in teaching-learning process, which can influence the gaining of successful goals at schools. They are curriculum, materials, method, teachers, students and facility. All parts are related each other and cannot be separated. The two active parts are who is to teach and students who are to learn.

Reading is one of the competences to be developed in SMP education level. This competence is important because by this skill, readers can get information 
Journal of Educational Method and Technology Vol. 2 No. 2, Agustus 2019

P-ISSN 2622-8459 E-ISSN 2622-8467

http://ejournal.unima.ac.id/index.php/jemtec

knowledge. Comprehension and ideas from reading texts. It act of interpreting printed, written words.

Reading is a process of learning. Through reading people can get information, ideas and knowledge. Reading involves an interaction between thought and language.

There are many kinds of Reading texts such as, Descriptive, Narrative, Recount, Anecdote, Procedural, and Report. All of these texts have their own characteristics and objectives.

The characteristics of Descriptive text is different from Narrative text. Descriptive text emphasizes on description of features in order of importance, expressing cause and effect while Narrative text emphasizes on Expressing time; sequence, cause and effect and describing characteristics, and appearance.

Even though reading skill is given more emphasis in teaching English, the aim of teaching is not only to read a text but also to enable the students to understand fully the text being read.

The most common problem with SMP students is that they canot read comprehensively and fluency even a simple English text found in the text book or packkaged books used in the teaching learning process in the classroom. They do not understand the ideas in the texts and cannot read them properly. This problem also faced by the students of SMP Negeri 3 Ratahan, particularly the second-grade students.

\section{Review of Literature}

\section{Question and Answer Technique}

Question and answer technique is questions, which are used to ask the contents of reading passage, " Question are usually answerable .by directly quoting from the passages "(Murdoch, 1982:2). The statement above implies that question anad answer technique may give readers some information about what they are reading.

\section{Reading}

According to Miller (1977:7) that "Reading means that process of communication from one to another through the medium of writing or printing. More concisely, the purpose of reading is speaking the idea behinds the words."

Finochiarro and Bonomo's (197a:119) define reading as "bringing meaning to and getting meaning from printed or written material". This is similar to Miles (1975), who also points out that reading is decoding written words, so that they can be produced orally. It is the ability to anticipate meaning in line of print, but not concerned with the mechanical but with grasping ideas from groups of words that the convey meaning.

It is commonly realized that reading is not a simple activity and it plays an important role in human life because the readers know something by reading. The readers can increase their knowledge and understanding of what authors intend, their ways of thinking, their contemporary activity and their contribution to many fields. By reading people usually have specific purposes which reading serve reading which is intended to get information about something, reading for enjoyment, reading which is done to solve some problems and reading some evaluation. Reading 
motivates creative thinking and interest because with reading people learn new thing, which can help in our life.

There are a number of reading forms, and also built on a number of various purposes, for instance, reading which is intended to get information about something, reading for enjoyment, reading which is done to solve problems, and reading some evaluation. Thus, reading can be classified into two types, i.e. reading for information and reading for pleasure. In this context, reading is concerned mainly with learning to recognize the printed symbols that represent language and to respond intellectually and emotionally when being asked about the content of the text he has read (Aber \& Edward 1981). Reading is ... not a reaction to a text, but an interaction between writer and reader mediated through the text ... reading efficiency is a matter of how effective a discourse the reader can create from the text either in term of report with the writer or in term of his purpose in engaging in the discourse in the first place (VViddowson 1979:30). The above definitions explain that reading is the combination of word recognition, intellect and emotion interrelated with prior knowledge to understand the message communicated.

The above quotation means that reading is the simple activity, it is more than pronouncing the written quote to the spoken one it also means understanding or comprehending printed material with serve its purpose.

\section{Reading Comprehension}

Reading comprehension is a thought process through which readers became aware of an idea understand it, in term of the experimental background and interpret it in relation to their own needs and purposes (Kennedy, 1981:192). It means that reading comprehension is an understanding and utilizing of information and ideas gains through interaction between the reader and the author. This indicates that in reading comprehension the reader does not only read in order to get the idea but also to interpret and to evaluate of what he has read.

Nuttal (1982:22) also states that "Reading comprehension is an active thinking process that depends not only on comprehension skill but also on the students' experience and prior knowledge". Comprehension involves understanding the vocabulary, sees the relationship among words, organizations of ideas and recognizing the authors' purpose. It is clear that reading comprehension is a thinking process where the reader understands or comprehend a text being read based on the knowledge or experience that he already has.

\section{Descriptive Text}

Descriptive text or essay, telss how something looks, feels, smells, tastes, and/or sounds. In descriptive texts and essay, ideas or sentences are organized in a spatial order. Spatial order is the arrangement of items in order by space.

Basically, the purpose of descriptive text is to describe or to inform something. The description about a person, animal, or things.

\section{Applying Question and Answer Technique in Teaching Reading Comprehension}

The following procedures are followed in teaching reading comptrehension through question and answer technique 
Journal of Educational Method and Technology Vol. 2 No. 2, Agustus 2019

P-ISSN 2622-8459 E-ISSN 2622-8467

http://ejournal.unima.ac.id/index.php/jemtec

Step 1

1. Giving students generally explanation about the text.

2. Asking students read the text silently.

3. Giving them test and scoring the students' achivement.

Step 2

1. Teacher reads the text.

2. Asking students to read the text silently.

3. Asking students to identify the new words or vocabulary

4. Students answer the question.

5. Teacher correct the answer.

\section{Methodology \\ Research Design}

This study is classified as quantitative through pre-experimental design with one group pre-test and post-test desiogn. According to Hatch and Farhady (1982:20) that "Pre-test and post-test is similar to one shot case study. The difference is that a pre-test is given before instrcution or treatment begins, so tehre are two tests. T1 is pre-test and T2 is post-test, $\mathrm{X}$ is to symbolize the treatment.

\section{Population and Population}

The population of this research is the students of SMP Negeri 3 Ratahan. It was limited only to the second-year students, there were 30 students.

\section{Data Collection}

The instrument used in collecting data is test. The first test is pre-test which is given before treatment and the second test is post-test which is given after treatment. The kind of test are completion and multiple choice.

\section{Data Analysis}

In analyzing the data, the writer used mean score formula. Hatch and Farhady (1082:30) state that: $X=\frac{\Sigma X}{N}$

$$
\begin{aligned}
& \mathrm{X}=\text { Mean score } \\
& \Sigma X=\text { All score of the sample } \\
& \mathrm{N}=\text { Total of student }
\end{aligned}
$$


Journal of Educational Method and Technology Vol. 2 No. 2, Agustus 2019

P-ISSN 2622-8459 E-ISSN 2622-8467

http://ejournal.unima.ac.id/index.php/jemtec

\section{Data Analysis}

Tabulation of Data

Table 1. The score of stiudents in Test 1

\begin{tabular}{|c|c|}
\hline Students & $\begin{array}{c}\text { Score } \\
\left(\mathrm{T}_{1}\right)\end{array}$ \\
\hline 1 & 5 \\
\hline 2 & 5 \\
\hline 3 & 6 \\
\hline 4 & 6 \\
\hline 5 & 6 \\
\hline 6 & 6 \\
\hline 7 & 5 \\
\hline 8 & 6 \\
\hline 9 & 7 \\
\hline 10 & 6 \\
\hline 11 & 6 \\
\hline 12 & 6 \\
\hline 13 & 5 \\
\hline 14 & 6 \\
\hline 15 & 5 \\
\hline 16 & 6 \\
\hline 17 & 6 \\
\hline 18 & 6 \\
\hline 19 & 5 \\
\hline 20 & 7 \\
\hline 21 & 6 \\
\hline 22 & 7 \\
\hline 23 & 5 \\
\hline 24 & 6 \\
\hline 25 & 6 \\
\hline 26 & 6 \\
\hline 27 & 6 \\
\hline 28 & 5 \\
\hline 29 & 5 \\
\hline \multirow[t]{2}{*}{30} & 6 \\
\hline & 168 \\
\hline
\end{tabular}

$$
\begin{aligned}
& \text { Mean }=\frac{\Sigma X}{N} \\
& X=\text { Mean score } \\
& \mathbf{x}=\text { Mean } \\
& \Sigma X=\text { Total of scores }
\end{aligned}
$$


Journal of Educational Method and Technology Vol. 2 No. 2, Agustus 2019

P-ISSN 2622-8459 E-ISSN 2622-8467

http://ejournal.unima.ac.id/index.php/jemtec

$$
\begin{aligned}
\mathrm{N} & =\text { Number of student } \\
\Sigma & =168 \\
\mathrm{~N} & =30 \\
& =\frac{168}{30} \\
& =5,5
\end{aligned}
$$

\begin{tabular}{|c|c|}
\hline Students & Score $\left(\mathrm{T}_{1}\right)$ \\
\hline 1 & 8 \\
\hline 2 & 7 \\
\hline 3 & 8 \\
\hline 4 & 8 \\
\hline 5 & 8 \\
\hline 6 & 9 \\
\hline 7 & 7 \\
\hline 8 & 8 \\
\hline 9 & 9 \\
\hline 10 & 8 \\
\hline 11 & 8 \\
\hline 12 & 8 \\
\hline 13 & 7 \\
\hline 14 & 7 \\
\hline 15 & 6 \\
\hline 16 & 8 \\
\hline 17 & 8 \\
\hline 18 & 8 \\
\hline 19 & 7 \\
\hline 20 & 9 \\
\hline 21 & 9 \\
\hline 22 & 9 \\
\hline 23 & 7 \\
\hline 24 & 8 \\
\hline 25 & 8 \\
\hline 26 & 8 \\
\hline 27 & 8 \\
\hline 28 & 7 \\
\hline 29 & 6 \\
\hline \multirow[t]{2}{*}{30} & 8 \\
\hline & 234 \\
\hline
\end{tabular}

Table 2. The Score of Students in Test 2 


$$
\begin{aligned}
& \text { Mean }=\frac{\Sigma X}{N} \\
& \mathrm{X}=\text { Mean score } \\
& \overline{\mathrm{X}}=\text { Mean } \\
& \Sigma \mathrm{X}=\text { Total of scores } \\
& \begin{aligned}
\mathrm{N} & =\text { Number of student } \\
\Sigma & =234 \\
\mathrm{~N} & =30 \\
& =\frac{234}{30} \\
& =7,8
\end{aligned}
\end{aligned}
$$

Table 1 shows that there were 30 students took part in the test. There were three students got in increased by three (3) points higher, there were twenty-five (25) students got two (2) points, higher and there were two ( 2 ) students got one (1) point.

Table 3. The Frequency Distribution Matrix of Pre-Test $\left(T_{1}\right)$

\begin{tabular}{|c|c|c|c|c|c|}
\hline Score & Tally & Frequency & Cumulative & Cumulative & Cumulative \\
& & & Frequency & Proportion & Percentage \\
\hline 7 & $/ / /$ & 3 & 30 & 1 & 100 \\
\hline 6 & X// $/ / / /$ & 18 & 27 & 0,90 & 90 \\
\hline 5 & $X / / / /$ & 9 & 18 & 0,60 & 60 \\
\hline
\end{tabular}

Table 4. The Frequency Distribution Matrix of Post-Test $\left(\mathrm{T}_{2}\right)$

\begin{tabular}{|c|c|c|c|c|c|}
\hline Score & Tally & Frequency & Cumulative & Cumulative & Cumulative \\
& & & Frequency & Proportion & Percentage \\
\hline 9 & $/ X / 10$ & 3 & 1 & 100 \\
\hline 8 & $X / / X / /$ & 16 & 25 & 0,83 & 83 \\
\hline 7 & $/ X / /$ & 7 & 18 & 0,60 & 60 \\
\hline 6 & $/ /$ & 2 & 11 & 0,37 & 37 \\
\hline
\end{tabular}


Journal of Educational Method and Technology Vol. 2 No. 2, Agustus 2019

P-ISSN 2622-8459 E-ISSN 2622-8467

http://ejournal.unima.ac.id/index.php/jemtec

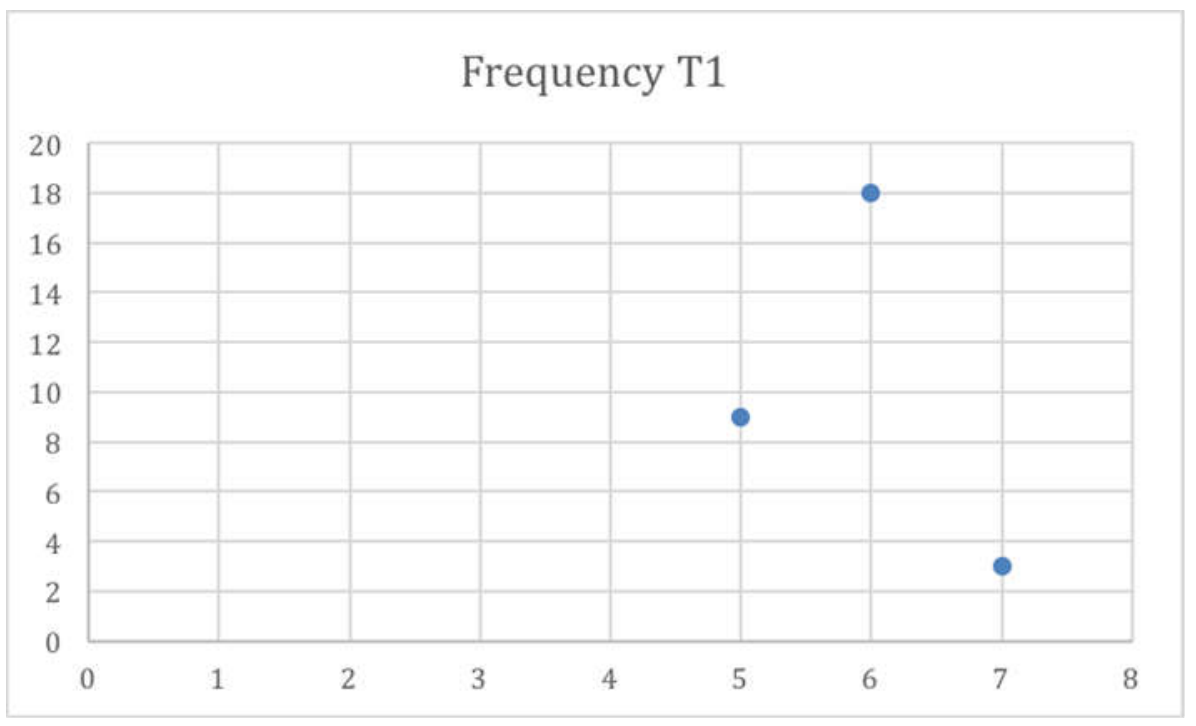

Figure 1. The frequency of the pre-test score (T1)

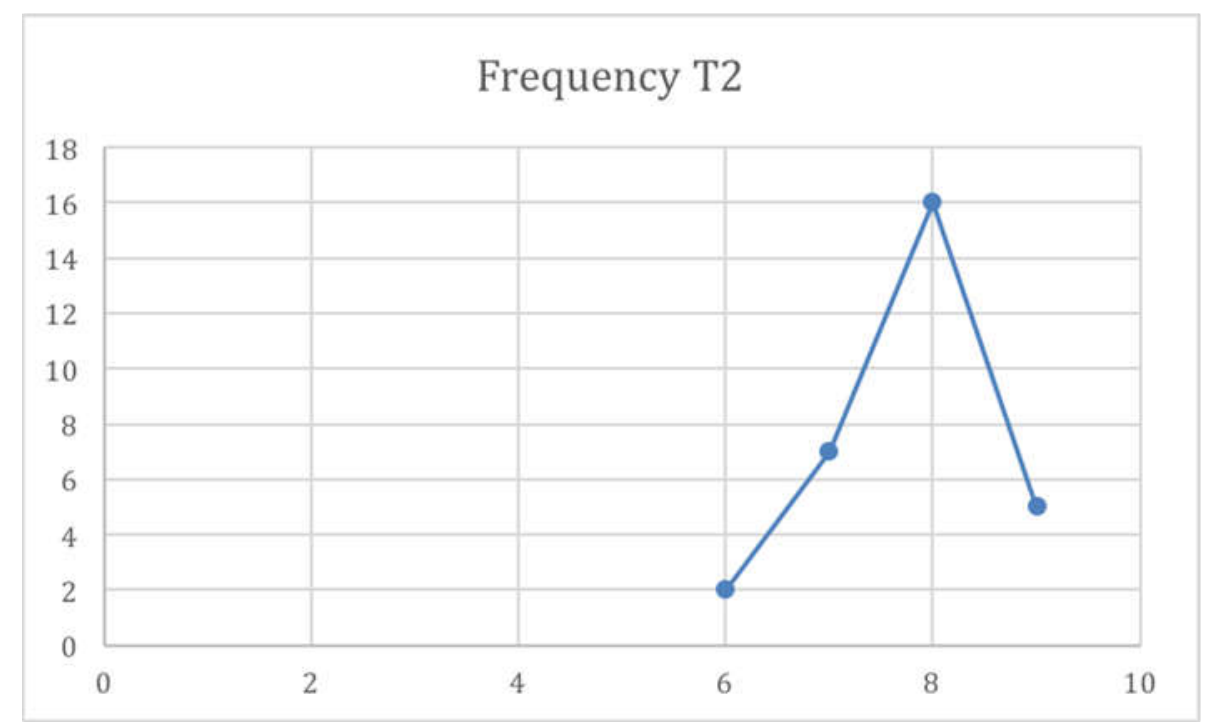

Figure 2. The frequency polygon of the post-test score (T2) 


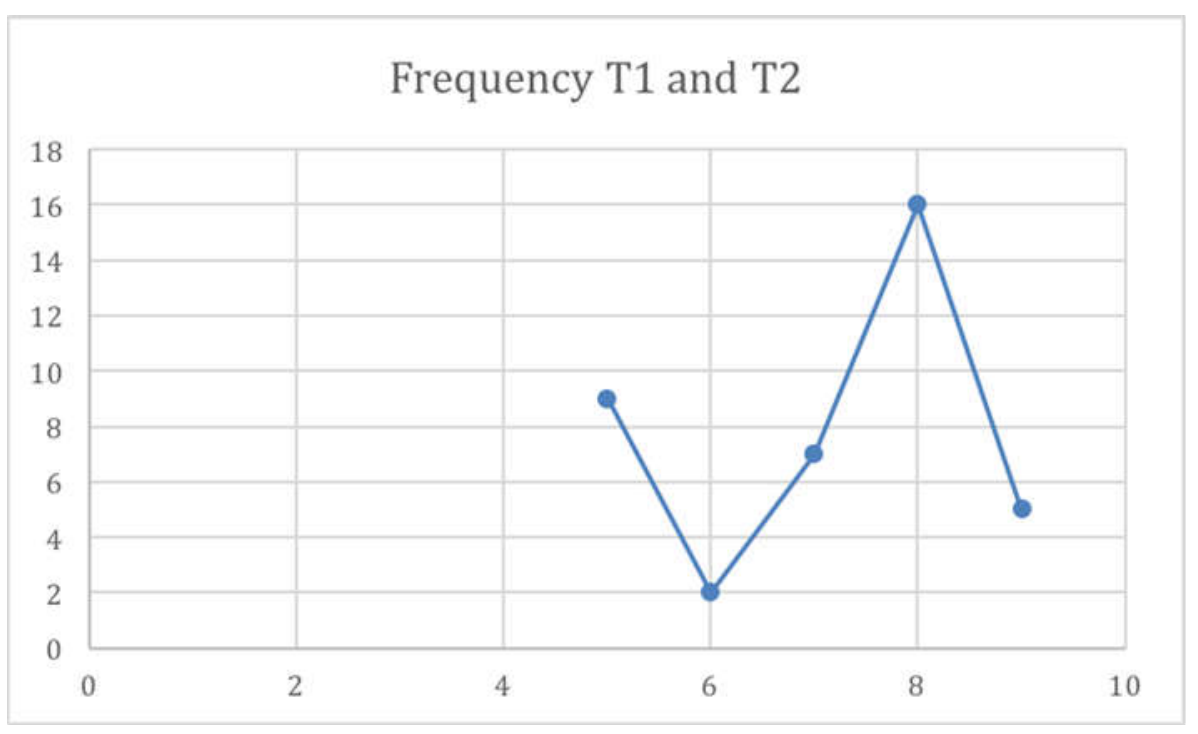

Figure 3. The frequency polygon of the pre-test (T1) and post-test(T2)

There were thirty (30) students took part in test. In pre-test, the highest score is seven (7) achieved by three students, six (6) achieved by eighteen (18) student), and the lowest score is five (5) achieved by nine (9) students). The mean score of pretest is 5.5 .

In post-test the highest score is nine (9) achieved by five (5) students, eight (8) achieved by sixteen (16) students, seven (7) achieved by seven (7) students, and the lowest score is six (6) achieved by two students. The mean score of post-test is 7.8. It is concluded that the result of post-test is much better that pre-test.

The result of indicates that question anad answer technique is effective to develop students' reading comprehension of descriptive text. The score of the posttest is higher than the score of pre-test.

\section{Conclusion and Suggestion \\ Conclusion}

The result shows that question and answer technique can help teacher to conduct teaching and learning process of reading comprehension. The scores of posttest were higher that the pre-test. It means that descriptive text by using question and answer technique was proved better. The mean score of pre-test which is 5.5 and mean score of post-test which is 7.8.

Question and answer technique can create a good teaching and learning. The atmosphere makes the students become interested and motivated in learning English especially reading text.

\section{Suggestion}

1. English teachers have to use question and answer because the technique is an effective way to develop students' reading comprehension.

2. This technique can motivate students to learn actively and intensively. 
Journal of Educational Method and Technology Vol. 2 No. 2, Agustus 2019

P-ISSN 2622-8459 E-ISSN 2622-8467

http://ejournal.unima.ac.id/index.php/jemtec

\section{References}

Brown, H.D. 1980. Principle of Learning and Teaching. New Jersey: Practice Hall

Clark,L.H. and Star,L.S. 1981.Secondary and Middle School Teaching Methods. New York : McMillan Publisher Co.Inc.

Croft.1980. Reading English as a Second Language. Cambridge Winthrop Publisher Inc.

Finocchiaro, M \& M. Bonomo. 1974. The Foreign Language Learner Guide for Teacher. Raegent Publishing Company.

Gay.R.L. 1981. Educational Research . Columbus, Charles B. Merril.Co.

Hatch, E.H. Farhady. 1982. Research Design and Statistics for Applied Linguistics. Rowley: Newburg House Publisher.

Kennedy, E.E. 1981 Method in Teaching Development Reading. West

Virginia University of Illinois F.E. Pencock Publisher Inc.

Larsen, D. \& Freeman. 1986. Technique and Principles in Language

Teaching. New York: Oxford University Press.

Miller, L.L.1977. Increasing Reading Efficiency. United States of America: Prentice Hall,

Nuttal,G. 1982. Road to Reading . Washington Panthograph Inc.

Olson and Diller. 1982. Reading in the Elementary School. Boston allyn and Bacon.

Strevans, Petter. 1977. New Orientation in Teaching of English. Oxford University Press.

Webster M. Webster's Ninth New Colligiates Dictionary. Massachusets. 1990.

Zints, 1975. The Reading Process. New Mexico W.M. Brown Company

Publishers. 